\title{
Sprawozdanie
}

\section{Międzynarodowe seminarium naukowe nt.: Rozwój konstytucjonalizmu na Ukrainie i w Polsce: historia i wspótczesność, Kijów, 10 marca 2011 r.}

W dniu 10 marca 2011 r. w Kijowie odbyło się międzynarodowe seminarium „Rozwój konstytucjonalizmu na Ukrainie i w Polsce: historia i współczesność". Zostało zorganizowane przez Wydział Prawa Kijowskiego Narodowego Uniwersytetu im. T. Szewczenki oraz Wyższą Szkołę Prawa i Administracji w Przemyślu.

Seminarium było centralnym punktem spotkania Prezydium Polsko-Ukraińskiego Klubu Konstytucjonalistów. Idea powstania Klubu zrodziła się w 2005 r. z inicjatywy prof. dr hab. J. Posłusznego, Rektora Wyższej Szkoły Prawa i Administracji w Przemyślu, podczas Międzynarodowej Konferencji Naukowej O potrzebie zmian Konstytucji Polski i Ukrainy zorganizowanej w Krasiczynie przez WSPiA oraz Wydział Prawa Uniwersytetu im. I. Franki we Lwowie (spraw. zob. „Administracja, Teoria, Dydaktyka, Praktyka” 1/2005 s. 105-108). Współprzewodniczącymi Klubu są prof. dr hab. W. Skrzydło i prof. dr hab. W. Szapował, a zadaniem członków Klubu jest stałe obserwowanie pojawiających się w obu państwach propozycji zmian konstytucji i dokonywanie ich wspólnej oceny na konferencjach odbywających się na przemian w Polsce i na Ukrainie. Dotychczas odbyły się dwie takie konferencje. W grudniu 2006 r. w Kijowie oraz na przełomie września i października 2008 r. w Sieniawie (spraw. zob. „Administracja, Teoria, Dydaktyka, Praktyka" 2/2009 s. 225-229). Ich efektem są publikacje: Suczasyj konstytucjonalizm: doswid nowych demokraty, Kijów-Lwów 2008 oraz Problemy prawa wyborczego Polski i Ukrainy, Przemyśl-Rzeszów 2010.

W seminarium, którego obrady toczyły się w siedzibie Wydziału Prawa Uniwersytetu w Kijowie uczestniczyli deputowani ludowi Ukrainy, sędziowie Sądu Konstytucyjnego Ukrainy, przedstawiciele Administracji Prezydenta Ukrainy, Instytutu Państwa i Prawa Ukraińskiej Akademii Nauk, Instytutu Prawa Rady Najwyższej Ukrainy, Narodowej Akademii Zarządza- 
nia Państwem przy Prezydencie Ukrainy oraz konstytucjonaliści z uniwersytetów w Kijowie, Charkowie i Czerniowcach. Stronę polską reprezentowali obok przedstawicieli WSPiA, profesorowie z Uniwersytetu Marii Curie-Skłodowskiej w Lublinie, Uniwersytetu Mikołaja Kopernika w Toruniu, Uniwersytetu w Gdańsku i Szkoły Głównej Handlowej w Warszawie.

Obradom przewodniczyli - Dziekan Wydziału Prawa Kijowskiego Narodowego Uniwersytetu im. T. Szewczenki prof. I. Hryszczenko oraz Rektor WSPiA prof. J. Posłuszny. Seminarium składało się z dwóch części. W pierwszej, poświęconej współczesnym tendencjom zmian w prawie konstytucyjnym Polski i Ukrainy, referaty wprowadzające wygłosili prof. M. Koziubra i prof. W. Skrzydło. Następnie odbyła się wielowątkowa dyskusja. W drugiej części zaprezentowano książkę prof. P. Steciuka, sędziego Sądu Konstytucyjnego Ukrainy, Persza konstytucija Polszczi (1791). Sproba prawowoho anali$z$ u, Lwów 2010.

Profesor M. Koziubra przypomniał najnowszą historię ustroju Ukrainy. Od uchwalenia konstytucji w 1996 r., poprzez jej głęboką nowelizację w 2004 r., po orzeczenie Sądu Konstytucyjnego z dnia 1 października 2010 r. uznające tę nowelizację za niekonstytucyjną i powrót do regulacji w wersji z 1996 r. Omówił dyskutowaną na Ukrainie koncepcję stworzenia Zgromadzenia Konstytucyjnego, jako organu doradczego przy Prezydencie, złożonego z konstytucjonalistów, polityków, przedstawicieli organizacji społecznych i obywateli. Zadaniem Zgromadzenia ma być wypracowanie w perspektywie dwóch-trzech lat reformy systemu politycznego Ukrainy i przedstawienie Prezydentowi projektu kompleksowej nowelizacji konstytucji, który zgodnie z procedurą określoną w rozdziale XIII Ustawy Zasadniczej zostanie wniesiony pod obrady Rady Najwyższej.

Profesor M. Koziurba zaznaczył, iż niezbędnym warunkiem powodzenia tego przedsięwzięcia jest uzyskanie dla niego szerokiego poparcia społecznego. Jego zdaniem zmiana konstytucji Ukrainy jest niezbędna i to nie tylko w zakresie kompetencji prezydenta, rządu i parlamentu ale także w części dotyczącej praw człowieka. Szczególnie zwrócił uwagę na zbyt deklaratywne regulacje w zakresie praw socjalnych, które znacznie odbiegają od standardów europejskich, w tym także od rozwiązań przyjętych w Polsce. Mówił również o konieczności reformy zasad powoływania sędziów Sądu Konstytucyjnego. Stwierdził, iż nie jest zwolennikiem uchwalania zupełnie nowej konstytucji Ukrainy ale uważa, iż zmiany ustrojowe powinny mieć głęboki 
charakter i muszą zmierzać w kierunku wzmocnienia gwarancji przestrzegania Ustawy Zasadniczej.

Profesor W. Skrzydło rozpoczynając swoje wystąpienie zauważył, iż w Polsce podobnie jak na Ukrainie, permanentnie trwa dyskusja konstytucyjna i podejmowane są próby nowelizacji konstytucji. W okresie od $1989 \mathrm{r}$. do 2010 r. w polskim parlamencie zarejestrowano łącznie 70 projektów pełnych konstytucji i projektów częściowej zmiany konstytucji, w tym kilkanaście już po wejściu w życie konstytucji RP z 1997 r. Tak częste, nierzadko nieprzemyślane, inicjatywy nowelizacji konstytucji W. Skrzydło uznał za szkodliwe. Z drugiej strony zauważył, iż mija już 7 lat od akcesji a wciąż nie wprowadzono do Ustawy Zasadniczej regulacji związanych z członkowstwem Polski w Unii Europejskiej.

Bardziej szczegółowo prof. W. Skrzydło omówił dwa kompleksowe projekty nowelizacji polskiej konstytucji - projekt byłych prezesów Trybunału Konstytucyjnego oraz projekt posłów Platformy Obywatelskiej. Wykazał, iż wiele $\mathrm{z}$ przewidywanych $\mathrm{w}$ nich rozwiązań jest próbą wyeliminowania problemów jakie powstawały w procesie stosowania obowiązującej konstytucji.

Dłużej zatrzymał się także na zmianach w prawie wyborczym związanych z uchwaleniem Kodeksu Wyborczego (przypomniał, iż część z nich było realizacją postulatów uczestników konferencji Klubu Konstytucjonalistów w Sieniawie) oraz na reformie Prokuratury.

Podsumowując prof. W. Skrzydło wyraził wątpliwość co do możliwości wprowadzenia jakikolwiek zmian do konstytucji RP jeszcze przed jesiennymi wyborami parlamentarnymi. W odpowiedzi na pytanie prof. O. Marcelaka opowiedział się za reformą, ale nie za zniesieniem drugiej izby polskiego parlamentu, a w odpowiedzi na pytanie prof. W. Kostyckiego za silną władzą rządu, a nie prezydenta.

W czasie dyskusji poruszono między innymi problemy współczesnego rozumienia idei podziału władzy oraz stabilności systemu prawa. Profesor Z. Niewiadomski posługując się argumentami opartymi na licznych przykładach polskich unormowań prawnych, postawił tezę o erozji zasady podziału władzy (stwierdził, że dzisiaj należy raczej mówić o podziale kompetencji, a nie o podziale władzy) oraz wykazał szkodliwość częstych zmian ustawodawstwa.

O wartości jaką stanowi trwałość ustroju mówił także prof. M. Kostecki. Przypomniał, że zarówno Polska jak i Ukraina od początku XX wieku mia- 
ły po kilka konstytucji „ale ilość nie zawsze przechodziła w jakość”. Poruszył problem konieczności uwzględniania przy konstruowaniu systemów rządów specyfiki poszczególnych państw i społeczeństw, ich tradycji oraz historycznych doświadczeń. Opowiedział się także za stworzeniem na Ukrainie dwuizbowego parlamentu.

Profesor Z. Witkowski w swoim wystąpieniu zajął się kilkoma konkretnymi problemami, które pojawiają się przy okazji projektowanych zmian w konstytucji RP. W szczególności kwestią sposobu wyłaniania prezydenta. W konkluzji stwierdził, że mimo licznych i oczywistych wad powszechnych wyborów głowy państwa, w Polsce nie można już powrócić do wyborów pośrednich. Należy raczej dążyć do wprowadzenia zaostrzonych warunków kandydowania na urząd prezydenta. Na przykładzie wyników ostatnio przeprowadzonych wyborów uzupełniających do Senatu, zwrócił także uwagę na niebezpieczeństwa jakie wiążą się z wprowadzeniem jednomandatowych okręgów w wyborach do tej Izby. Podkreślił, iż w praktyce konstytucyjnej ogromną rolę odgrywają kultura polityczna i osobowość przywódców. Opowiedział się również przeciw, jego zdaniem, zbyt częstym zmianom w prawie wyborczym zarówno w Polsce jak i na Ukrainie.

Ukraińscy uczestnicy dyskusji zwracali uwagę na występujące w ich państwie rozbieżności pomiędzy teorią a praktyką konstytucyjną. Eksperci wielokrotnie wskazują na konieczność ustawowego uregulowania wielu materii a stosowne akty prawne wciąż nie powstają. Profesor A. Kołodij jako przykład podał potrzebę uchwalenia ustaw o Radzie Najwyższej Ukrainy, o opozycji, o organach wymiaru sprawiedliwości czy o reformie terenowej administracji państwowej.

Profesor A. Szmyt nawiązując do tematu seminarium zwrócił uwagę na historię idei ograniczenia do niezbędnego minimum zmian w konstytucji. Przytoczył poświęcone jej realizacji stosowne przepisy Konstytucji 3 maja i konstytucji z 1921 r. Opowiedział się za stworzeniem stałej parlamentarnej komisji konstytucyjnej, której zadaniem byłoby dokonanie analizy całego tekstu konstytucji RP z punktu widzenia koniecznych nowelizacji.

Profesor W. Kolisnyk podał przykłady niewykonywania dyspozycji norm ukraińskiej konstytucji i braku właściwej reakcji Rady Najwyższej, co jego zdaniem przyczynia się do stałego spadku zaufania społecznego do parlamentu. Natomiast prof. I. Koliuszko opowiedział za większym udziałem naukowców w pracach nad reformą konstytucji Ukrainy. 
W dyskusji wystąpił także Dyrektor Instytutu Państwa i Prawa Akademii Nauk Ukrainy prof. J. Szemszuczenko zwracając uwagę na konieczność wykorzystania doświadczeń Polski w procesie przebudowy ustroju samorządu terytorialnego na Ukrainie.

W drugiej części seminarium prof. P. Steciuk przedstawił swoją książkę poświęconą Konstytucji 3 maja: Pierwsza Konstytucja Polski (1791): próba analizy prawnej. Uczestnicy seminarium podkreślali, że dzięki tej publikacji po raz pierwszy na Ukrainie ukazało się nie tylko studium prawne polskiej Ustawy rządowej z 1791 r., ale także jej pełny tekst, zarówno w oryginale, jak i w tłumaczeniu na język ukraiński. Zwracano uwagę na oryginalną metodę analizy treści Konstytucji 3 maja z wykorzystaniem współczesnej teorii prawa konstytucyjnego.

Na zakończenie seminarium współprzewodniczący obrad prof. I. Hryszczenko oraz prof. J. Posłuszny podziękowali za bogatą dyskusję wskazując na dużą zbieżność problemów z jakimi spotykają się naukowcy i politycy z Polski i Ukrainy reformując ustrój swoich państw.

Krzysztof Eckhardt (Wyższa Szkoła Prawa i Administracji w Przemyślu) 